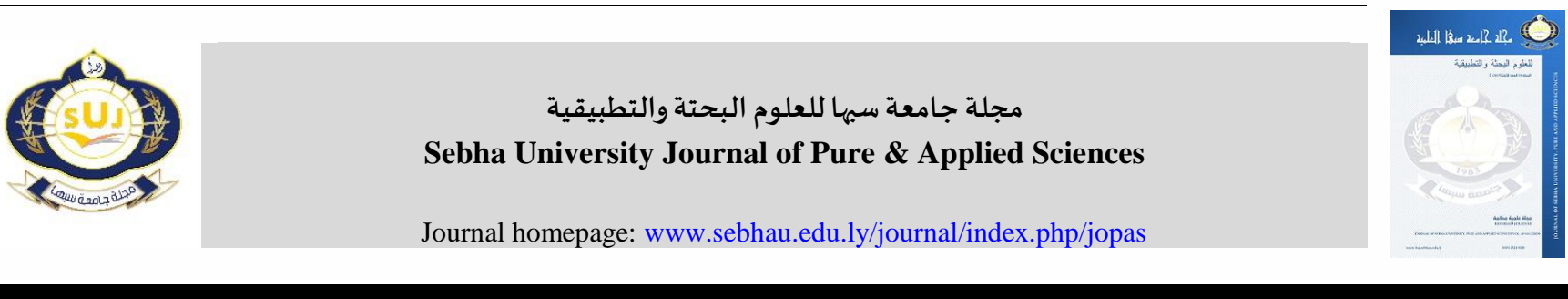

\title{
Fostering Quality in the Graduation Research Project at the Libyan Faculties of Education: Libyan Teacher-Educators' Perspectives
}

*Entisar Elsherifa ${ }^{\mathrm{a}}$ Fuzia Elhsan ${ }^{\mathrm{b}}$

${ }^{a}$ English Language Department, Faculty of Education/University of Tripoli, Libya

${ }^{b}$ Mathmetics Department, Faculty of Education/University of Tripoli, Libya

\section{Keywords: \\ graduation project \\ graduation research project graduation research project quality quality assurance \\ undergraduate research}

\begin{abstract}
A B S T R A C T
One of the Libyan Faculty of Education exit requirements is the graduation research project. Current literature review indicates the scarcity of literature on the quality of the graduation project in the Libyan context. Thus, the present study addressed this shortcoming by investigating the opinions of the faculty members at the Faculties of Education at various Libyan public universities on achieving quality standards in the graduation research projects. The design of the study was exploratory sequential mixed methods as we gathered both quantitative and qualitative data to get accurate and detailed picture of the Libyan teacher-educators' views on fostering quality in the graduation research project. The context of the study is the Faculties of Education at eight Libyan universities. The participants were 62 Libyan teacher-educators who were faculty members at the Libyan Faculties of Education. Data were collected through documents, questionnaires, and follow up interviews. The results showed that the participants' views were opposite to the document analysis and revealed that the participants were not sure whether the regulations covered all the points related to the graduation research projects, so they preferred to be neutral. They also perceived several factors as the issues that hindered the quality of the graduation research projects. The participants suggestions as ways of fostering quality in the graduation research projects included achieving quality by following the quality standards described by the quality assurance department among other suggestions.
\end{abstract}

$$
\begin{aligned}
& \text { تعزيز الجودة في بحث مشروع التخرج في كليات التربية الليبية: وجهات نظر أعضساء هيئة التدردس الليبيين } \\
& \text { * انتصار علي الشريف1 و فوزية أحمد الحصان2 } \\
& \text { 1ققسم اللغة الانجليزية، كلية التربية طرابلس، جامعة طرابلس، ليبيا }
\end{aligned}
$$

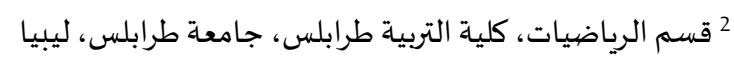

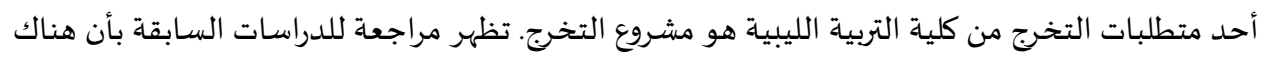

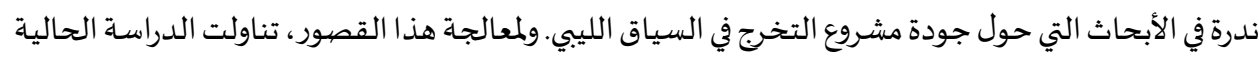

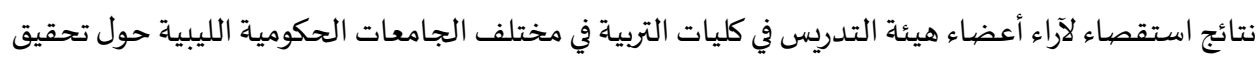
معايير الجودة في أبحاث مشاريع التخرج. تم تصيميم الدراسة بطريقة البحث الاستكشافي المختلط حيث فيثاء قمنا

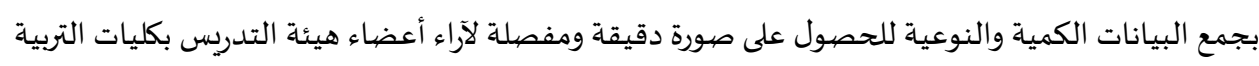
حول تعزيز الجودة في مشروع التخرج. كان عدد المشاركون 62 عضو من أعضياء هيئة التدريس في كليات التربية

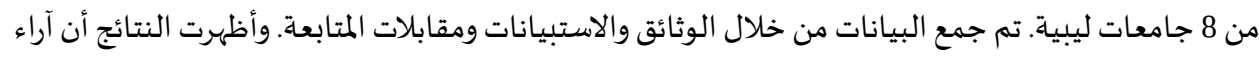

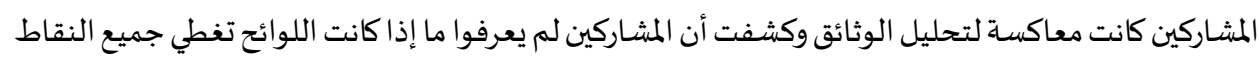

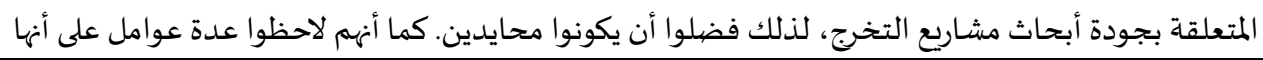

\section{*Corresponding author:}

E-mail addresses: e.elsherif@uot.edu.ly, (F. Elhsan)F.Elhsan@uot.edu.ly 


$$
\text { التخرجايا التي أعاقت جودة مشاريع التخرج. تضمنت اقتراحات المشاركين كطرق لتعزيز الجودة في مشاريع أبحاث الجودة باتباع معايير الجودة التي وصفها قسم ضمان الجودة من بين مقترحات أخرى }
$$

\section{Introduction}

Like its counterparts around the world, the primary aim of the Libyan Faculty of Education is to prepare the student-teachers to become effective teachers. The main objective of all the teacher preparation programs at the Faculty of Education is helping the student-teachers gain a foundation of knowledge about pedagogy and subject matter and providing them with opportunities for practical classroom experience [1].

Using innovative teaching methods and approaches strengthens the interconnections between teaching, learning, and research. The three innovative instructional approaches that offer the student-teachers with the chance for undergraduate research are inquiry-based teaching, reliance on evidence-based interventions, and reflection on practice [2]. Taking these approaches into account, teacher education programs also provide the student-teachers with the chance to conduct research as training opportunities that help them understand the significance of research in improving educational practices, resolving classroom problems, and determining ways of enhancing their future learners' lives [3]. For this reason, one of the Libyan Faculty of Education exit requirements is the graduation project.

The graduation project is a final-year exit requirement that follows a pre-determined structured course known as Research Methodology

(طرق البحث). In their graduation research projects, the student-

teachers are required to conduct research under the supervision of one of the faculty members who has the expertise in the investigated topic. They are assessed not only on their understanding of their field of study but also on how successful they were in reporting their research results and findings academically in their theses.

Graduation projects are one of many forms of undergraduate research. Undergraduate research experiences can take many forms such as course-based activities, course-based projects, capstone experiences, and student-faculty collaborative research [5]. Undergraduate research is defined as "an inquiry or investigation conducted by an undergraduate student that makes an original intellectual or creative contribution to the discipline" [4]. Research shows evidence of undergraduate research positive outcomes in teacher education [6], [7], [2]. undergraduate research is an "important experiential learning opportunity" [8] as it (1) provides the student-teachers with opportunities to gain problem-solving, critical thinking, analytical and statistical skills [9], (2) broadens their understanding of the various educational practices, and (3) determines ways of resolving classroom problems and enhancing their future learners' lives through research [3]. The main features of undergraduate research are the choice of the topic, independent learning, proposal preparation, data collection, data analysis, research ethics, and writing the thesis [10].

Having to go through the process of conducting the research project and writing the thesis is valuable to the student-teachers as it prepares them for their future career as teacher-researchers. Being prepared as a teacher-researcher is beneficial because it prepares the studentteachers to carry out research in their classroom and schools, transforms teaching, and promotes reflective practice [11]. Since the graduation project is usually done in groups, it also aims at raising student-teachers' groupwork and cooperative skills with the aim of promoting collaborative teaching and research. This is because research has proven the value of teacher collaboration and its positive impact on teachers and learners [12], [13].

Since undergraduate research is a valuable experience for both the student-teachers and their communities, all universities around the world are fostering standards of research quality. Research quality mostly refers to the process of study design [14]. More specifically, it is about matching the methods and questions, selecting the subjects, measuring the outcomes, and protecting against bias and inferential error [14]. Quality of research is also defined in terms of being conducted on time, rigorously designed, being internally and externally valid, depending on reliable data sources, and using of appropriate analytical methods [15]. Achieving research excellence is not an easy process as there are many factors that are affecting the quality of undergraduate research. Mahammoda classified the factors affecting the quality of undergraduate research as academic, psychological, institutional, social and personal factors [16]. Students' poor analytical, critical thinking, and language skills, and their unwillingness to complete the research were the academic factors. Students' lack of motivation and being unconfident were the psychological factors. Ineffective time organization skills, not being able to meet their mentors regularly, and participants' reluctance to partake were the social and personal factors. Finally, updated textbooks unavailability and library resources dearth were the institutional factors. [16]

To achieve quality in undergraduate research, universities must consider strategies and procedures that minimize and eliminate those factors. Rowlett, Blockus, and Larson specified and discussed twelve characteristics of excellence in undergraduate research that universities need to consider to achieve quality in undergraduate research. These characteristics include (1) creating a research campus culture, (2) reassigning appropriate time for faculty for researchrelated tasks, (3) enhancing research infrastructure by providing appropriate space, equipment, and other research resources, (4) providing professional development opportunities to both students and faculty, (5) providing clear, tangible forms of recognition for faculty and students, (6) providing external funding, (7) providing chances for dissemination to students, (8) incorporating the best practices in undergraduate education, (9) designing curricula that expose students to skills necessary to undertake undergraduate research, (10) offering a robust summer research program, (11) having multiple approaches to assessment, and (12) having thoughtful and clearly articulated benchmarks and strategic plans [4]. Research on undergraduate research in the Libyan context can be considered scarce as only three studies were found, all of them were not related to teacher education programs. The first study investigated the hypothesis that Libyan university students rarely fulfil the required standards of empirical research in their graduation projects. The findings of this study showed that students showed misconduct in their citation and referencing, did not follow the primary stages of empirical research, and had poor proofreading skills as their final drafts included many common errors in grammar, punctuation, and word choice [17]. In the second study, Alsied and Ibrahim investigated challenges faced by Libyan EFL students at Sebha University in research writing. Their findings revealed that students had problems in choosing their research topics, formulating research problems, collecting and analyzing data, and writing literature reviews, methodology, results, and discussion chapters of their thesis. The factors' behind these problems were students' lack of knowledge of what constitutes research writing, the unavailability of Internet access and library resources, and students' unwillingness to work and achieve success [18]. In the third study, Elmabruk and Bishti explored the students and staff attitudes and their perceived challenges regarding the addition of graduation projects as an exit requirement of the Department of English at the Faculty of Languages. Their findings indicated that the challenges include students' lack of research skills, inexperienced supervisors, inadequate resources, and concerns with plagiarism [19].

Review of the current literature on undergraduate research in the Libyan context also shows that there exists a dearth of literature on the quality of the graduation project. To address this shortcoming, the present study investigates the opinions of the faculty members of the Faculties of Education at various Libyan public universities on 
achieving quality standards in the graduation research projects. To achieve quality in student-teachers' graduation projects, there is a need to understand the existing graduation research project quality related policies and procedures, specify the factors affecting the quality of graduation research project, and identify how quality of undergraduate research can be achieved.

\section{Methodology}

This exploratory sequential mixed methods study is part of a larger research project that is conducted by two of the Faculty of Education Tripoli departments: The Research, Consulting, and Training Department and the Quality and Performance Evaluation Department. Its aim was to examine the teacher-educators' perceptions on achieving quality standards in the graduation research project. To achieve this aim, three research questions were raised:

1. What are the views of the Libyan teacher-educators on the graduation research project quality related policies and procedures?

2. What obstacles affect the quality of graduation research project as viewed by the Libyan teacher-educators?

3. How can the quality of the graduation research project be achieved from the Libyan teacher-educators' perspective?

The exploratory sequential mixed methods design was chosen because it facilitates triangulation and helps us gain an accurate and detailed picture of the Libyan teacher-educators' views and perceptions on fostering quality in the graduation research project [20]. This design gave us the chance to begin with an initial qualitative data collection and analysis phase, follow that with the quantitative data collection and analysis phase, and then end up with the final phase in which we integrated and linked our data collected in the previous phases [20].

\section{Research sites and participants}

The target population of this research was Libyan Teacher-educators who are faculty members at Libyan public universities around Libya. The participants of the study were 62 teacher-educators from ten Faculties of Education at eight universities. Fifty-two participants were from University of Tripoli, three of the participants were from Al-Mergeb University, and two participants were from Sebha University. Only one respondent participated from each of the following universities: University of Benghazi, University of Zawia, Misurata University, Sirte University, and Azzaytuna University.

Thirty-six of the teacher-educators held a masters' degree whereas 25 of them held a Ph.D. One participant preferred not to respond to this question. The participants' departments ranged as they were from 15 departments: Arabic Language, Arabic Language \& Islamic Studies, Biology, Chemistry, Classroom Teacher, Computer, Education \& Psychology, English Language, Geography, Islamic Studies, Kindergarten, Mathematics, Physics, Sociology, and Special Education.

\section{Data collection}

Data were gathered through documents, questionnaires, and followup interviews. Data collection procedures began by gathering the documents. The study began by gathering the documents from the University of Tripoli at the Faculty of Education Tripoli and then checked the university website for the availability of the documents. Then, other universities' websites were checked. The gathered documents included the 501 Regulation document, research ethics policies (وثيقة البحث العلمي) \& لائحة 501 ), and the graduation project student handbooks.

The following stage was distributing the questionnaires. Because of the different research area and sites, validation of the questionnaire items was done through content validity. The content of the questionnaire was checked for validity by two teacher-educators from the Faculty of Education Tripoli and one professor from the Faculty of Engineering. It was also proofread and checked for any ambiguity by a teacher-educator from the Arabic Department at the Faculty of Education Tripoli. All suggestions were considered, and changes were made accordingly. The final form of the questionnaire included five categories: demographic information, teachereducators' knowledge of and perceptions on regulations and policies, factors hindering quality, and teacher-educators' suggestions on achieving quality (see Table 1).
Table 1. Types of questions and their description

\begin{tabular}{ccl}
\hline Items & $\begin{array}{c}\text { Type of } \\
\text { Questions }\end{array}$ & \multicolumn{1}{c}{ Description } \\
\hline Q1- Q3 & Closed-ended & $\begin{array}{l}\text { Demographic information: degree, } \\
\text { faculty-university, department. }\end{array}$ \\
\hline Q4 - Q20 & Closed-ended & $\begin{array}{l}\text { teacher-educators' perceptions on the } \\
\text { availability of university/faculty } \\
\text { regulations and guiding handbooks }\end{array}$ \\
\hline Q21 & Closed-ended & $\begin{array}{l}\text { teacher-educators' perceptions on } \\
\text { factors hindering achieving quality in } \\
\text { graduation research projects }\end{array}$ \\
\hline Q22 & Open-ended & teacher-educators' suggestions on \\
Q23 & Open-ended & \\
\hline
\end{tabular}

The reliability of the questionnaire was 0.75 (good). Google Forms was used in the distribution of the questionnaire. The questionnaire was distributed through social media, Facebook and Viber, academic and professional groups in November 2020.

Follow up interviews were made through phone calls and social media texting or voice calls. The aim was to clarify any ambiguity or uncertainty that the researchers faced in understanding the teachereducators' responses in the questionnaire. The participants were ten teacher-educators from the Faculty of Education Tripoli.

\section{Data analysis}

This study is a qualitative-dominant mixed methods in which the iterative sequential mixed analysis was utilized. Data analysis was in three phases. We began with an initial qualitative data analysis phase, followed that with the quantitative data analysis phase, and then ended up with the final phase in which we integrated and linked our data collected in the previous phases.

After line-by-line reading and memoing, a thematic inductive approach was used to code and analyze the qualitative data that was gathered from documents and interviews [21]. Arab Processor in Social Statistics (APSS) was used to analyze the quantitative data. A final phase of data analysis was done with the aim of using combined qualitative and quantitative data in the presentation of the study findings. In the following section, we provide a brief discussion of the findings in narrative thematic order.

\section{Results}

In this study, we explored the perceptions of 61 Libyan teachereducators about the graduation project quality related policies and procedures, the factors hindering achieving quality in the graduation projects, and their suggestions for achieving quality. In this section, we discuss the major findings.

1. Libyan teacher-educators' perceptions on the graduation project quality related policies and procedures

The questionnaire included 14 statements for which the respondents had to choose from a 3-point scale that included agree, disagree, and to some extent. The 17 statements were analyzed qualitatively and quantitatively. Then, findings from documents, questionnaires, and interviews' analysis were combined and were organized into 6 themes that are discussed in the following sections.

\subsection{Perceptions on the Libyan Ministry's "501 Regulation" document}

The teacher-educators were asked to respond to a statement regarding the "501 Regulation." The 501 Regulation is a document issued by the Libyan Ministry of Education and includes all the policies and regulations organizing the Libyan higher education. All Libyan universities follow this document's regulations.

On pages 24-25 of the document, there are five policies that are specifically about the graduation project and numbered as $95,96,97$, 98 , and 99 . They cover the graduation project plan policy, assessment policy, deferring policy, grading policy, and innovative project award achievement policy. Unlike the section on the graduate research, the undergraduate research section of the 501 Regulation does not include any information related to research ethics and plagiarism. A 3-point scale was used to explore the teacher-educators' perceptions on whether the 501 Regulation document included all the organizational and procedural rules and policies related to the 
graduation research project. $59 \%$ of the respondents chose "to what extent," which showed some uncertainty, whereas $28 \%$ of them agreed with the statement. Only $13 \%$ of the participants disagreed stating that the 501 Regulation document did not include all the organizational and procedural rules and policies related to the graduation research project.

Since document analysis revealed that the 501 Regulation did not cover all the significant points related to the graduation research project, a follow up interview was conducted to explore the views of the respondents who chose "to some extent". The interview analysis revealed that they have chosen "to some extent" either because they had no previous knowledge about the graduation project section in the document or because they were not sure as they have not read document.

\subsection{Perceptions on the research ethics document}

Like other universities around the world, Libyan universities have research ethics policies known as "أخلاقيات البحث العلمي". The Research Ethics Policy documents establish an over-arching framework of ethical principles for good ethical practice during research conduct to increase research quality. Our initial analysis of the availability of such document on the websites of the universities of the respondents revealed that only 2 universities had this document available on their websites, which are the University of Tripoli and Sebha University. As for the other Libyan universities, it was not easy to locate them.

The respondents were asked to respond to four statements regarding their perceptions about their universities' research ethics document. The results indicated that there was uncertainty on the availability of the research ethics document as $52 \%$ of the respondents chose "To some extent" as response to whether their university had a research ethics document that includes all the organizational and procedural rules and regulations related to the graduation project. Follow up interviews revealed that this uncertainty is a result of having no knowledge on such document or not having read the document before.

Forty-two percent of the respondents believed that their Faculty of Education does not have research ethics policy that guarantees adherence to research procedures and ethics whereas $38 \%$ of them agreed. Only $20 \%$ of the respondents chose to "some extent" to indicate some uncertainty as revealed in interview data analysis.

When respondents were asked whether the student-teachers knew about the research ethics policy, nearly half of the respondents (49\%) disagreed, whereas the other half of them were divided between being uncertain $(25.50 \%)$ and believing that the student-teachers knew about the research ethics policy document $(25.50 \%)$.

Finally, data also revealed that the respondents neither agreed that their Faculty of Education has a system that shows the studentteachers the consequences of not respecting academic honesty and research ethics, nor agreed that the student-teachers know that the Faculty of Education has research ethics policy that guarantees adherence to research procedures and ethics. When respondents whether the student-teachers knew about the research ethics policy, nearly half of the respondents $(49 \%)$ disagreed, whereas the other half of them were divided between being uncertain $(25.50 \%)$ and believing that the student-teachers knew about the research ethics policy document $(25.50 \%)$.

Nearly forty-eight percent of the respondents believed that their faculty has a system that shows the student-teachers the consequences of not respecting academic honesty and research ethics. While nearly twenty-four percent of the participants agreed that there is a policy for plagiarism and research misconduct, nearly $30 \%$ of them chose "to some extent" to show uncertainty. Interview results showed that the participants did not see any written form of regulations or policies on plagiarism and research misconduct.

\subsection{Perceptions on the graduation project student handbook}

The graduation project student handbook is known as " دليل مشروع

”. The handbook is a document that is supposed to provide the student-teachers with the significant procedural rules and policies regarding the graduation project. Even though we are sure that most of the faculties, at least, have such document, the only university that had a copy of its graduation project student handbook on its website is Sebha University. We were not able to locate this document from any other university's website. We were able to gather the Faculty of Education Tripoli's handbook as both departments had copies.

The questionnaire included three statements that aimed at exploring the teacher-educators' perceptions about the graduation project handbook.

Forty-two percent of the participants believed that their university does not have a graduation research project handbook that includes an explanation of all the organizational and procedural rules that guide student-teachers' research, whereas $33 \%$ of them were not sure and showed uncertainty by choosing "to some extent." Only $25 \%$ agreed with the statement. These results are affirmed by interview results as all the interviewees stated that faculty graduation handbooks did not cover all the organizational and procedural rules. Respondents also showed uncertainty with regard to the statement that indicates "The Faculty of Education has a graduation research project handbook that includes an explanation of all the organizational and procedural rules that guide student-teachers' research" as $38.20 \%$ of them chose "to some extent." The percentage of respondents who agreed and disagreed with the statement were similar (30.90\%). Interview analysis supported the questionnaire results in that the participants thought that graduation project lacked some of the procedural rules and did not provide a complete guide. The respondents also showed uncertainty in that each department of the Faculty of Education has a graduation project handbook that includes an explanation of all the organizational and procedural rules that guide student-teachers' research as nearly half of the respondents chose "to some extent" $(49.10 \%)$. Nearly twenty-eight percent of the respondents disagreed whereas nearly $24 \%$ agreed. Interview data analysis revealed that some of the teacher-educators' departments did not have the handbook. Other teacher-educators indicated that some of the procedures are orally passed to department faculty as there was not written forms of those rules and procedures.

\subsection{Perceptions on the assessment of the graduation project}

To explore the perceptions of the teacher-educators on the graduate projects' assessment, four statements were included in the questionnaire. First, the respondents had to respond to whether their Faculty of Education had a clear procedure for the graduation projects' assessment. There was uncertainty as nearly fifty-five percent of the respondents chose "to some extent". Nearly thirtyeight respondents agreed of having clear procedures for assessment where only $7.30 \%$ of them disagreed. Interview data showed that in most of the participants' departments, assessment rubrics were used to assess the student-teachers research. However, some of them did not accept the criteria of assessment used by their departments. Similarly, the results showed that $56.40 \%$ of the respondents were not sure whether their faculty has a clear procedure for the studentteachers' performance assessment. However, $32.70 \%$ of them agreed of having a clear procedure for the student-teachers' performance assessment. Only $10.90 \%$ disagreed. Interview data showed that the teacher-educators uncertainty was due to the fact that some of the departments did not have a clear procedure for assessment.

The shocking result came in the respondents' views on whether their departments have recording and documentation procedures for the graduation project evaluation processes as $40 \%$ of them disagreed and $40 \%$ were not certain. Only $20 \%$ of the respondents agreed of having procedures to record and document graduation projects' assessment. It was shocking as the norm is that all assessment are documented in papers and electronically. Interview results showed that some of the teacher-educators thought that the statement was ambiguous whereas the other respondents thought that the statement referred to the documentation of the theses.

Thirty-eight percent of the teacher-educators agreed that the criteria for evaluating the quality of the graduation project include the quality of the subject being investigated, the level of the student's capabilities as a researcher, and the quality of the research results, whereas $14.50 \%$ disagreed. However, $47.30 \%$ of the teacher-educators preferred not to be certain by choosing "to some extent". Interview results showed that assessment varies from one field to another and from one teacher-educator perspective to another. Thus, there was a variation in the respondents' perceptions.

1.5. Perceptions on benefitting from the graduation projects 
One of the indicators of quality standards in research is how faculties benefit from distinguished graduation projects. Thus, the questionnaire included 2 statements on which we asked the respondents to specify their views. Firstly, our data showed that more than half of the respondents opposed the view that their Faculty of Education has clear procedures to benefit from the student-teachers' distinguished graduation project results $(65 \%)$ whereas only $16 \%$ of them had a positive view. Nearly twenty per cent of the respondents chose "to some extent" as they were not sure if their faculties had any kind of service to benefit from the distinguished projects.

For the second statement, data revealed that nearly three quarters of the respondents believed their departments of the Faculty of Education do not have any procedures to help the student-teachers to publish the results of their research in refereed journals. Really small number of the respondents $(8 \%)$ agreed of having publishing procedures for their undergraduates. Follow up interview showed that they referred to a small number of projects in applied sciences that get to be published because of the mentors. $19 \%$ of the respondents were not sure whether their programs had such procedures, which is why they chose "to some extent."

\section{Teacher-educators' perceptions on factors hindering achieving} quality in graduation research projects

To answer the second research question, the questionnaire included a closed-ended question and an open-ended question. The closedended question included 12 statements from which the respondents had to specify the obstacles hindering the quality of the graduation project from their point of view. The 12 statements were grouped into four groups: $80 \%, 70 \%, 60 \%$, and $50 \%$. Absence of student-teachers' motivation to conduct the graduation project as researchers was reported as the most affecting factor in achieving the graduation project quality $(82 \%)$. Four statements were gathered in the $70 \%$ group. Seventy-four percent of the respondents thought that lack of interest in offering informative workshops and seminars that aim to show the importance of their research to society and education to the student-teachers as another important factor. The other affecting factors were the unavailability of laboratories, and their tools and equipment in applied sciences research (72\%), lack of interest in offering training courses that explain to students how to conduct research and how to write a thesis $(72 \%)$, and the unavailability of support programs for scholarly and scientific research (72\%). Four statements were grouped in the $60 \%$ group. Sixty-eight percent of the respondents reported that absence of clear organizational rules and procedures that show the significance of quality in the graduation project as a scholarly/scientific research in the Faculty of Education and that lack of references, periodicals and scientific journals as the two factors that have similar effect on the quality of undergraduate research. In addition, $66 \%$ of the respondents believed that studentteachers' misconduct by committing theft of others' work due to their lack of knowledge of the principles of writing research and their inefficiency in academic writing as another factor affecting the quality of undergraduate research. Besides, $62 \%$ of the respondents considered universities' and faculties' lack of interest in offering training courses that qualify the mentors to supervise studentteachers in their graduation research projects as another factor hindering the quality of undergraduate research. In the final group, more than half of the teacher educators $(58 \%)$ believed that lack of clear policies about the objectives and importance of the graduation research project as a scholarly/scientific research for the Faculty's students as future teachers affected the quality of the graduation projects. $52 \%$ of the teacher-educators thought that the unavailability of technology and Internet access and irrelevance of the research carried out in the faculty to the problems of the local community as the least affecting factors on the quality of undergraduate research. The other question that asked the participants to specify the constraints of the graduation project quality was open-ended so that the teacher-educators note those factors that were not mentioned in the previous questions. Most of the mentioned points supported the previously mentioned factors. Some of the teacher-educators added the student-teachers' language proficiency as an affecting factor that influence the undergraduate research quality.

3. Teacher-educators' suggestions for achieving quality

The third research question inquired about the ways by which the quality of the graduation research project be achieved from the Libyan teacher-educators' perspective. Thus, the questionnaire included an open-ended question that encouraged the teachereducators to propose suggestions to achieve quality standards in undergraduate research. Data analysis resulted in having seven themes that are briefly discussed in the following paragraphs.

3.1. Regulations and policies reformation: Some of the participants acknowledged the necessity of regulations and policies reform. They thought the ministry should reform higher education study and examination regulations to include more detailed policies and rules regarding undergraduate research with clear definition of plagiarism and precise description of what constitutes plagiarism and its consequences.

3.2. Designing, implementing, and sustaining a research supportive undergraduate program: The teacher-educators' emphasis was on research informed teaching. They suggested a teacher education curricular reform in which all curricular elements develop the student-teachers' critical thinking and research skills by implementing inquiry-based learning, problem-based learning, cooperative learning, and project-based learning as a way to broaden learning outcomes. In addition, the participants believed that research basics should be taught to students from the first semester with the aim of improving their research skills. They also suggested adding homework and assignments that require research, investigation, and dealing with data and information in most of the programs' courses to help the student-teachers to learn the basics of research.

3.3. Redesigning the research-related courses: The teachereducators suggested that all the prerequisite courses of the graduation projects, such as Academic Writing (الكتابة الأكاديمية), Fundamentals

of Statistics (مبادئ الاحصياء), and Research Methodology ( طرقيه

البحث (ا), should have a practical part in which the student-teachers be trained by conducting research and writing research papers as part of the course requirements. They believe that the practical part should be an integral part of the course assessment instead of just relying on mid-term and final exams' grades as the course assessment. They also suggested that the Research Methodology course should be taught as two courses in which the students learn about qualitative and quantitative research methods in details.

3.4. Raising students' awareness of research ethics and plagiarism: the participants urged that there should be courses in which the students learn about research ethics and how to avoid plagiarism. They also emphasized the significance of informing student-teachers on the consequences of being accused as a plagiarist. 3.5. Raising awareness on the significance of research to local communities: Teacher-educators emphasized the necessity of community-based research. Thus, they assured the relevance of undergraduate research to the local community and the active role of the student-teachers in removing various social and cultural barriers and resolving different community problems through research.

3.6. Educational support services: Teacher-educators assured the significance of providing educational support services to the studentteachers. They acknowledged the potency and availability of library resources, Internet access, and university official bookstore. They also asserted the importance of having up-to-date resources in the library and providing access to local and national databases. In addition, they highlighted the necessity of having well-equipped laboratories for applied sciences' research. Besides, they asserted the significance of having faculty's bookstore that should sell all required course materials, textbooks, books, school supplies, other types of merchandise.

3.7. Offering Training opportunities: Nearly all the teachereducators suggested offering free of charge on campus training courses that could be for a day, a couple of days, or a week. Following is a summary of the suggested training courses:

- Training courses for student-teachers: the teachereducators suggested offering training courses that would prepare the student-teachers for their research projects with emphasis on raising the students' awareness on the worth of their research projects to themselves, the faculty/university, and to the local community. The also teacher-educators asserted the significance of offering 
courses that improve the student-teachers' academic writing and courses on using technology with emphasis on using PowerPoint.

- $\quad$ Training courses for mentors: Teacher-educators suggested offering courses that would train mentors on guiding the student-teachers and giving effective feedback. As choosing the right and worth researching topic is challenging for many student-teachers, teacher-educators believed that it is vital to provide guidance and assistance in the process of choosing their research topics.

\section{Conclusion}

Quality of undergraduate research in essential in creating a culture that values research as well as to benefit the community by solving its problems through research. To achieve quality in undergraduate research, faculties of Education have to raise the student-teachers' awareness to the significance of their research to their communities. In this study, we tried to explore the perceptions of the Libyan teacher-educators on the graduation research project quality related policies and procedures, the obstacles affecting the quality of graduation research project, and ways that can help in achieving the quality of the undergraduate research. The findings of the study encourage future researchers, university professors, and the Libyan ministry professionals and administrators to consider the seriousness of undergraduate research and work towards improving the current status by working on the challenges that influence the quality of undergraduate research and improving performance through regulations reformation and providing professional development opportunities through training courses.

\section{Researchers' recommendations}

Recently, there is an increasing concern in what constitutes achieving quality standards among all Libyan universities. For this reason, we provide the Libyan ministry and universities with the following recommendations:

- There is an urgent need to reform the 501 Regulation to include more details about the graduation project as a scholarly/scientific research so that it creates a culture that values research and research ethics.

- Create a Libyan Council on Undergraduate Research considering Characteristics of Excellence in Undergraduate Research (COEUR) [4].

- Developing a rigorous research ethics document and graduation project guide/handbooks that lead the university students to achieve quality.

- Offer training opportunities for both student-teachers and faculty to achieve quality in undergraduate research.

- Provide educational support and research infrastructure to encourage the student-teachers and their mentors for achieving quality research by having adequate library and computational resources, appropriate space, equipment, and other research resources.

- $\quad$ Provide opportunities to use and benefit from virtual Labs for STEM students [22].

- Promote dissemination by encouraging student-teachers to disseminate their undergraduate research, though publications, conference presentations, exhibitions, or other forms of academic performance.

\section{Limitations of the study}

This study's main limitation is the number of the participants as it does not represent the whole population. Fr instance, views from only one participant from one university does not give a realistic picture of the teacher-educators' perceptions on fostering quality in undergraduate research.

Even though we asked three university professionals to check our questionnaire for validity and ambiguity, some of the teachereducators reported not understanding of some of the statements, which lead them to choose "to some extent" as they were not sure about the meaning of the statement.

Suggestions for further research

The researchers suggest further studies on:
1. How mentors guide their student-teachers to achieve quality in their undergraduate research.

2. whether the Research Methods course succeed or fail to prepare the student-teachers to conduct their graduation projects and achieve research quality.

\section{References}

[1]- M. J. Feuer, R. E. Floden, N. Chudowsky, \& J. Ahn, Evaluation of teacher preparation programs: Purposes, methods, and policy options. Washington, DC: National Academy of Education, 2013.

[2]- S. DeVore, \& D. Munk, (2015). Undergraduate Research in Teacher Education: A Rationale for Broader Engagement. Council on Undergraduate Research, 35(4), 12-17.

[3]- G. E. Mills, Action research: A guide for the teacher researcher (4th ed.). Boston: Pearson, 2011.

[4]- R. S. Rowlett, L. Blockus, \& S. Larsen, S. Characteristics of excellence in undergraduate research (COEUR). In N. Hensel (ed.) Characteristics of excellence in undergraduate research. Washington, DC: The Council on Undergraduate Research, 2012, 2-19.

[5]- S. B. DeLoach, E. Perry-Sizemore, \& M. O. Borg (2012). Creating quality undergraduate research programs in economics: How, when, Where, (and why), The American Economist, 57(1), 96-110.

[6]- J. T. Slobodzian, \& N. Pancsofar. (2014). Integrating undergraduate research into teacher training. CUR Quarterly 34(3), 43-47.

[7]- J. Manak, \& G. Young. (2014), Incorporating undergraduate research into teacher education: Preparing thoughtful teachers through inquiry-based learning. CUR Quarterly, 35(2), 35-38.

[8]- S. Wood, (2019). Undergraduate research assistant leadership for rigorous, high quality research. Front. Psychol, 10, 474-479.

[9]- K. MacKeogh, K. Supervising Undergraduate Research Using Online and Peer Supervision. In M. Huba (ed) 7th International Virtual University Conference, 19-24. Bratislava Technical University, Bratislava, 2006.

[10]- M. Todd, P. Bannister, \& S. Clegg, (2004) Independent Enquiry and the Undergraduate Dissertation: Perceptions and Experiences of Final Year Social Science Students. Assessment and Evaluation in Higher Education, 29 (3), 335-355.

[11]- C. M. Santa, \& J. L. Santa, (1995). Teachers as researchers. Journal of Reading Behavior, 27(3), 439-451.

[12]- D. E. Boland, K. B. Alkhalifa \& M. A. Al-Mutairi, (2019). CoTeaching in EFL classroom: The promising model. English Language Teaching, 12(12), 95-98.

[13]- R. Harat, (2012). Collaboration teaching and its role on education performance and student achievement. European Journal of Experimental Biology, 2(6), 2181-2187.

[14]- A. Boaz, \& D. Ashby, Fit for purpose? Assessing research quality for evidence based policy and practice. London: ESRC UK Centre for Evidence Based Policy and Practice, (2003).

[15]- S. T. Mahmood, (2011). Factors affecting the quality of research in education: students' perceptions. Journal of Education and Practice, 1(11\& 2), 34-39.

[16]- S. A. Mahammoda, (2016). Factors Affecting the Quality of Undergraduate Research Work in Bahir Dar University, Ethiopia. International Journal of Innovative Research and Development, 5 (12), 23-27.

[17]- A. Elmojahed, (2010) Writing Research Projects: Opportunities and Challenges, Journal of the Faculty of Education, 5, 40-62.

[18]- S. Alsied, \& N. Ibrahim, (2017). Exploring Challenges Encountered by EFL Libyan Learners in Research Teaching and Writing. IAFOR Journal of Language Learning, 3 (2), 43-158.

[19]- R. Elmabruk, \& R. Bishti, (2020). Returning to Graduation Project: Attitudes and Perceived Challenges of Students and Staff at a Libyan EFL Department. Arab World English Journal (AWEJ), 11 (3), 127-148.

[20]- P. Pardede, Mixed Methods Research Designs in EFL. In P. Pardede, EFL Theory and Practice: Voice of EED UKI. Jakarta, UKI Press, 2018, 230-243. 
[21]- A. J. Coffy \& P. A. Atkinson, Making sense of qualitative data: Complementary research strategies. Thousand Oaks, CA: SAGE, 1996.

[22]- O. Algudaire. (2020), Virtual labs and their impact on teaching laboratory aspects of conservative materials from the teachers' point of view. The First International Conference on Digital Education in Libya. 